\title{
REFLECTIONS ON JUSTICE
}

\author{
Rt Hon Sir Edmund Thomas*
}

This paper is an edited version of Sir Edmund's Valedictory Lecture delivered at the University of Auckland on 15 February 2018.

\section{INTRODUCTION}

It is not my intention to undertake a deep jurisprudential exposition of the complex subject of justice. Rather, this lecture represents the modest reflections of a retired judge who was at the judicial coalface in the administration of justice for some 16 years.

My reflections do, however, have a firm theme. The theme is that judges should give overt and transparent attention to the justice of a case as part of their reasoning in their judgments. ${ }^{1}$ Lord Steyn was inclined to say so towards the latter part of his tenure on the House of Lords. ${ }^{2}$ It is my regret that I did not disclose that the value judgement underlying and directing most of, if not all, my decisions was the value of justice.

* LLB (NZ) LLD (VUW) KNZM QC, High Court Judge 1990-1995, Judge of the Court of Appeal 1995-2001, Acting Judge of the Supreme Court 2005-2008. I would like to thank Professor David McLauchlan and Professor Francis Dawson for their wise counsel. I would also like to thank Louis Norton and Aroha Chinchanwala for their outstanding research and assistance. And I thank my wife, Margaret, for her painstaking attempts to correct my punctuation and grammar. Of course, I take full responsibility for the opinions expressed in the Lecture.

1 I would also suggest that it is open to legal academics to have regard to a court's adherence to the value of justice when writing a critique of a judgment.

2 Lord Steyn pursued the theme that judges should be guided by their perception of prevailing community standards and morality. Justice figured prominently in the standards and morality he articulated. It was in this way, he argued, that law and morality are inextricably interwoven. See for example Lord Steyn "Perspectives of Corrective and Distributive Justice in Tort Law" (2002) 37 IJ 1 at 1-15; Lord Steyn Democracy Through Law (New Zealand Centre for Public Law, Occasional Paper No 12, September 2002) at 14; Johan Steyn "Does Legal Formalism Hold Sway in England?" (1996) 49 CLP 43 at 43-44 and 58; McFarlane v Tayside Health Board [2000] 2 AC 59 (HL) at 82-83; Rees v Darlington Memorial Hospital NHS Trust [2003] UKHL 52, [2004] 1 AC 309 at [39]; Smith New Court Securities Ltd v Citibank NA [1997] AC 254 (HL) at 280; White v Chief Constable of South Yorkshire Police [1999] 2 AC 455 (HL) at 498; and Lister v Hesley Hall Ltd [2001] UKHL 22, [2002] 1 AC 215 at 6 and 12. 
In setting out my reflections, I have relied heavily on my book on the judicial process, The Judicial Process: Realism, Pragmatism, Practical Reasoning and Principles. ${ }^{3}$ Justice is a recurring theme in the book. It is apt that the loose cover depicts the Lady of Justice.

\section{THE LADY OF JUSTICE}

In her traditional posture, our Lady of Justice stands serenely blindfolded holding a pair of scales in the one hand and a sword in the other. The blindfold denotes that justice is blind to prejudice or pressure. Lord Denning has clarified that this does not mean she is blind to the truth. ${ }^{4}$ The scales are invariably held in an outstretched hand enabling them to perform their balancing faculty. The sword is more mobile. It is sometimes brandished aloft and at other times sheathed within the folds of the good Lady's ample skirt.

We all know why justice is blind. Justice is objective and impartial, administered without fear or favour. She bears no ill will to any litigant, and all are equal before the law. Thus, justice is evenhanded. The scales, we also know, symbolise the process by which one value or interest is balanced against another value or interest to ensure that justice is done. A fair weighing is an irredeemable element in achieving justice, and because judicial decision-making is essentially a balancing exercise the scales, at least in my perception, embody the judicial function. ${ }^{5}$

But, why the sword? A weapon? It seems incongruous that our Lady of Justice should bear arms. Strangely enough, no one seems to know why the Lady of Justice carries a sword.

Lord Denning has suggested that the sword is the symbol of the authority by which justice is done. ${ }^{6}$ No judgment of any court and no order of any judge, he reasons, is of any use unless it can be enforced, and to be enforced it requires the authority of the state behind it. Thus, the sword of justice is the sword of the state. "It is", Lord Denning proclaims, "the symbol of authority which must be upheld". 7

Lord Denning's conjecture that the sword symbolises the authority of the state can only be accepted in the broad sense that judgments and orders made in the courts are backed by the authority of the state. But the Lady of Justice holds out the promise that justice will be done in the individual

3 EW Thomas The Judicial Process: Realism, Pragmatism, Practical Reasoning and Principles (Cambridge University Press, Cambridge, 2005).

4 Jones v National Coal Board [1957] 2 QB 55 (CA) at 64:

It is all very well to paint justice blind, but she does better without a bandage round her eyes. She should be blind indeed to favour or prejudice, but clear to see which way lies the truth.

5 Developed in Thomas, above n 3, at 200-201, 271-272, 284-285 and 320.

6 Lord Denning The Closing Chapter (Butterworths, London, 1983) at 275-276.

7 At $276-277$ 
case. It is in that respect that Lord Denning's theory is deficient, because the authority of the state may be used to enforce a judgment or order which is unjust, or it may fail for a variety of reasons to enforce a judgment or order which is just. Enforcement or execution is a process which operates after justice has been done - or not done. It is an essential element of law and order, but not an integral facet of the justice administered in the courts.

I have been led to a less authoritarian explanation than that suggested by Lord Denning. Over the years, and particularly when on the bench, I noted that the law seemed to possess an underlying design. It repeatedly seeks to protect those who are vulnerable from being exploited by those in a position of power or dominance or having an unfair advantage of one kind or another. Hence, I concluded, the sword is there for the protection of those who are vulnerable and exposed to exploitation. But more of that anon.

\section{JUSTICE IN THE ABSTRACT?}

I begin with what I regard as a basic truism; the law is a social institution which exists to serve society. This dedication and subservience to the needs and expectations of society is the law's rationale and justification. Those that hold firm to the mystical notion that the law is independent and autonomous - a self-sufficient and self-sustaining discipline - must be dispatched to the bottom of the garden where they may blissfully romp with the resident fairies.

As the purpose and function of the law is to serve the society of which it is a part, it must strive to meet society's expectations. Prime among these expectations is the expectation that the law and the courts will deliver justice. People go to their lawyer in the first instance, and then to the courts, complaining that they have suffered a wrong and expecting the wrong to be righted. They seek justice and look to the law to provide that justice. They would rather see a Solomon on the bench than a walking epitome of Halsbury's Laws of England.

Justice, however, is an elusive concept. It seems to defy definition. The most intelligent and erudite of philosophers and legal theorists are unable to essay a determinative theory. When a comprehensive theory is attempted, as in the case of John Rawls, ${ }^{8}$ the forests of Chile are dramatically thinned as paper is produced to cope with the mountainous and never-ending criticism of that theory. It continues to irk us that no more explicit definition of a concept which is so central to society is attainable.

Consider for a moment the vast variety of senses in which we use the word "justice". We refer to corrective justice and distributive justice, to substantive or material justice and procedural justice, to legal or formal justice and social justice, to natural justice or due process, and to many more variants of this phenomenon called "justice".

8 John Rawls A Theory of Justice (Clarendon Press, Oxford, 1972). 
We take the Justinian precept that "justice is the set and constant purpose to give every man his due" without any general guidance as to what is a person's "due". 9

We equate impartiality with justice even though an impartial arbiter may arrive at a finding we consider substantively unjust.

We recoil in the name of justice at the notion that persons in an equal position should receive less than equal treatment unless some justification is proffered to explain the inequality or different treatment. We insist, again in the name of justice, on the ideal of basic human equality or worth, but temper its consequences with notions of merit. ${ }^{10} \mathrm{We}$ ally justice with notions of basic rights, entitlement, empowerment and the condemnation of oppression or domination. We assert an absolute or universal concept of justice, but are yet forced to concede that different cultures have different beliefs as to what is just and unjust.

But still, as the crescendo of disagreement and variation mounts, we strive for a unifying feature.

I have been brought to the view that it is monumentally difficult, if not impossible, to discern justice in the abstract. We seem unable to agree on its essence. Yet, we know from experience that justice exists in concrete situations. In such situations what is just or unjust will attract, if not universal agreement, at least, a broad consensus. Thus, justice has no readily abstract meaning divorced from a particular context. It is so multi-faceted and diverse that no universal or common element emerges to seize upon.

As already indicated, it is incomplete to say that justice requires that every person be given their due. ${ }^{11}$ What, then, is their due? The question is begged, at least until placed in a concrete situation in which an aggrieved person claims not to have received his or her due. Then, the argument becomes clear. There is then a reason why it is claimed that an act is that person's due or why a person has received something that is not his or her due. The unfairness is exposed. One only has to take the simple example of a neighbour who has borrowed one's lawnmower and failed or refused to return it to perceive what is the owner's due.

We do not appear to have the same difficulty distilling the abstract or universal meaning from other concepts such as, to take random examples, "dignity", or "humaneness", or "virtue", or "utilitarianism". To speak of the "dignity" of people is to speak of their essential worth as individual human beings; to speak of "humaneness" is to speak of benevolent or compassionate conduct; to speak

9 Also reported as "the constant and perpetual wish to render to every one his due", from Justinian Institutes (Samuel P Scott (translator), The Central Trust Company, Cincinnati, 1932). The Institutes are a part of the Corpus Juris Civilis, a collection of fundamental works in jurisprudence issued from 529 to 534 by order of Justinian I, Eastern Roman Emperor.

10 See Tom Campbell Justice (Macmillan Publishers, London, 1988).

11 See above $n 9$. 
of "virtue" is to speak of moral excellence and goodness; to speak of "utilitarianism" is to refer to the usefulness of some act for the benefit of, generally, the majority.

To speak of "justice", however, is to speak of "just conduct" or "fairness" or the assertion or maintenance of "right". We may as well say that "justice" is about justice or what is considered just or unjust. But we are then back to begging the question.

Our discourse reflects the fact we are much more comfortable with the negative concept of "injustice". I would suggest that this greater comfort arises because it is likely to be associated with a concrete situation in which justice has been denied - or it is alleged justice has been denied.

Justice, then, does not have a readily identifiable abstract meaning or a discernible essence. No universal or holistic definition seems possible. Justice, however, certainly exists in specific contexts. It is incorrigibly context-specific. Outside a specific context it loses its identity and attempts to capture its essence founder on its diversity and differentness.

But, if justice has no sensible meaning in the abstract, or at least it is beyond our human limitations to perceive it, what are we to do with the question "what is just?" or "what is fair?" We can, of course, continue to pursue endless philosophical discourses, which somewhere along the way tend to become exercises in linguistics or semantics. We can certainly undertake more empirical research in the hope that a common or unifying element will emerge. It may well be that we will accept that there is no unifying or common element and conclude that justice consists of a number of discrete concepts, each with its own abstract meaning or discernible essence, appearing under the loose banner of "justice".

In this quest I do not doubt that we can look to the sociologist or psychologist to assist in determining why and when people proclaim that something is just or unjust. This latter inquiry, I believe, probably represents the most productive avenue for determining whether and, if so, why, a vast and diverse group of contexts in which it may be said justice has been done can be legitimately grouped together as a distinctive category or categories.

Nor can I proffer the source of justice in the specific context. That is to say, I cannot provide a theoretical answer to the question why it is that most people would describe a certain act in a specific context as unfair or unjust. Their opinion will represent a sentiment immanent in the community and, seemingly, deeply rooted in the psyche of the individuals in that community. Why the community adheres to that sentiment, however, admits of no easy answer, and no doubt embraces answers relative to the history, culture and social and economic order of the society of which they are citizens.

At times, indeed, the sense of justice - or injustice - that can arise in certain circumstances can seem innate. Most of us have had the experience of observing an infant crying his or her eyes out when chastised for something they have not done. 
Ultimately, whatever its derivation, what is or is not just or fair in a certain context depends on a consensus within the community. Justice, I suggest, is not so much a political construct, as some would hold, as a community construct. Judges reflect this consensus immanent in the community. ${ }^{12}$

\section{JUSTICE FOR THE INDIVIDUAL}

The fact justice in the abstract does not lend itself to a ready definition and is incorrigibly contextspecific does not mean that it is any less important in the administration of the law. To the contrary, it becomes all the more pertinent, for the law as administered in the courts is very much concerned with the context-specific situations of individuals. It seeks to provide justice in the individual case having close regard to the facts of that particular case. It is through just decisions in these individual cases that the law is provided with its all-important moral direction.

I entertain no doubt that the law is sufficiently flexible to allow justice to be done in the instant case. Those who resist this perception are unaware of or ignore the extent of judicial autonomy and discretion. They have failed to perceive what Professor Unger of Harvard has called the "incorrigible indeterminacy" of the law, ${ }^{13}$ or what Professor Endicott from Oxford has described as the "vagueness" of the law, ${ }^{14}$ or what, not to be outdone, I have urged is the "inherent uncertainty" of the law. ${ }^{15}$

I need not expand on this vexed question in this article. Suffice to say, such indeterminacy, vagueness and uncertainty is part and parcel of the dynamic of the common law. That dynamic is fittingly captured by Benjamin Cardozo: ${ }^{16}$

The work of a judge is in one sense enduring and in another sense ephemeral. What is good in it endures.

What is erroneous is pretty sure to perish. The good remains the foundation on which new structures will

be built. The bad will be rejected and cast off in the laboratory of the years.

Within this dynamic there is ample scope for both the liberal and conservative judge to give overt recognition to the dictates of justice and thereby reinforce the moral direction of the law. The liberal judge will tend to do so by developing the law to accord with justice, and the conservative judge will do so simply by applying "the law" with its inbuilt predisposition to protect those who are vulnerable to exploitation.

12 For a full treatment of this aspect see Thomas, above n 3, at ch 15, especially at 367-374.

13 Roberto Mangabeira Unger Knowledge and Politics (Free Press, New York, 1975) at 242-243.

14 Timothy AO Endicott Vagueness in Law (Oxford University Press, Oxford, 2000) at 197-203.

15 Thomas, above n 3, at ch 5, especially at 108 and following. And, of course, learned counsel will generally press the "merits" of their client's case when they perceive that the justice of the case favours their cause.

16 Benjamin N Cardozo The Nature of the Judicial Process (Yale University Press, New Haven, 1921) at 178, as cited in EW Thomas "The laboratory of the years" [2005] NZLJ 297 at 299. 
Whether developing the law or applying "the law" to achieve justice (or to avoid injustice) in the individual case, judges must be meticulous in finding the correct facts and then applying analytical and logical reasoning - the hallmark of legal reasoning - to those facts. Obviously, if the court's findings as to the facts are erroneous there must be a strong possibility that justice will not be done. The decision will relate to "facts" which are not the true facts of the case. ${ }^{17}$ It will be entirely fortuitous if justice is done on facts which do not accord with what actually happened. Thus, getting the facts correct can be viewed as a prerequisite for doing justice. ${ }^{18}$ Similarly, if the court's reasoning based on those facts is loose, untidy or illogical, the scope for an injustice to infect the decision is that much greater. If, as already suggested, judicial decision-making is essentially a balancing exercise, loose, untidy or illogical reasoning will distort that exercise and necessarily give rise to a real possibility that an injustice will result. ${ }^{19}$

In truth, there is no substitute in the decision-making process for sound reasoning. If the court makes a statement and does not support that statement with a reason or reasons, it is nothing more than a bald statement or assertion. Nor will the statement gain in validity or plausibility if it is supported by a spurious reason. Any such bald statement or assertion which is not backed by valid reasoning introduces a random element into the decision-making process, and that random element is inimical to justice.

\section{EMPATHY}

I have long held the view that empathy has a close connection with justice. I am not referring to the empathy which can lead to divisive and harmful effects; the identification of a group as "us" and of those who are different as "them", with all the overtones of superiority and discrimination such a dichotomy entails. Rather, I am referring to our capacity to put ourselves in the position of another and perceive, understand and, indeed, feel, his or her situation; to stand in another's shoes and see the immediate world through their eyes and share their plight, their misgivings, their grievances and their pain. The reaction is other oriented, elicited by the perceived welfare of a person in need, at a disadvantage, different, out of their depth, or otherwise vulnerable. In this sense, empathy is to be seen as the motivation or driving force behind the desire to do justice.

17 For a detailed exposition of the importance of the facts see Thomas, above $\mathrm{n}$ 3, at 321-327. See also Jerome Frank Courts on Trial: Myth and Reality in American Justice (Princeton University Press, Princeton, 1973). As a jurist, Frank undertook a close examination of the fact-finding process of the courts.

18 "Forget the facts, and you forget the persons helped and hurt by the [courts'] decisions": John T Noonan Jr Narrowing the Nation's Power: The Supreme Court Sides with the States (University of California Press, Berkley, 2002) at 44; and "[t]he facts are the fount of individual justice": Thomas, above n 3, at 321.

19 See the case study below, GE Custodians v Bartle [2010] NZSC 146, [2011] 2 NZLR 31, for an example of a decision which gets the facts seriously wrong and then applies loose, untidy and illogical reasoning to those facts. 
In other words, it is empathy, or an empathetic concern, which prompts a consideration of the justice of a given situation and a desire to do justice in that situation.

Critics will argue, of course, that the law, and more particularly, a predictable law, cannot tolerate empathy. Yet others, such as myself, will see it as a counterpoint to the evil of formalistic thinking. ${ }^{20}$

\section{EQUALITY}

A related issue is the relationship of equality to justice, a relationship I have tended to pursue in the context of social justice. There, I have focused on the exploitation inherent in capitalism, neoliberalism and globalisation, particularly in relation to working people. ${ }^{21}$ In the course of these enlightened "rants" or "raves", I have questioned the worth of the mantra, "equality of opportunity". This mantra has the effect of obscuring, and is used to obscure, the true extent of inequality within the community. I hold to the view that equality must mean more than equality of opportunity. Certainly, everyone should have the opportunity to develop their talents to the full. But if equality means no more than that, it is simply the opportunity for those with a fortuitously superior genetic structure or fortuitously privileged background to advance their superiority or privilege. As a practical matter, the premise underlying equality of opportunity should be the existence of a level playing field, but genetics, ethnic and other prejudices, the economic order and liberal individualism effectively preclude that premise.

Yet, the law has its counterpart; that is, the time honoured principle that everyone is equal in the eyes of the law. No one should be at a disadvantage because of their status, gender, wealth, race, religion or any other factor extrinsic to the courtroom. But I would question whether that kind of equality is enough to satisfy the demands of justice.

I have looked for something more substantive for equality in the concept of justice than simply equality before the law. That substantive contribution, I believe, can be identified in one overriding respect: the claim of human beings to equal dignity.

Others have pointed out, and I have faithfully repeated, that underlying human rights is the dignity of the human person. ${ }^{22}$ Everyone has an equal right to claim that dignity and the rights that spring from it. ${ }^{23}$ Not only is everyone equal before the law; they are, or should be, equal in the law, and it is

20 For a sustained criticism of formalism see Thomas, above $\mathrm{n} 3$, at ch 3 .

21 See EW Thomas "Reducing Inequality: A Strategy for a Cause" (Bruce Jesson Memorial Lecture, October 2013); and EW Thomas "The Enduring Legacy" in David Cooke and others (eds) Beyond the Free Market: Rebuilding a Just Society in New Zealand (Dunmore Publishing, Auckland, 2014) 25.

22 Brooker v Police [2007] NZSC 30, [2007] 3 NZLR 91 at [177]-[182].

23 See EW Thomas "Bonker and Ors v The Police: Judgment of Athena J in the High Court" (2011) 19 Waikato L Rev 94, relating to the decision of the Supreme Court in Morse v Police [2011] NZSC 45, [2012] 2 NZLR 1. 
that equality that encompasses a wider and more profound perception of justice. The poor and the mighty, the powerless and the powerful, and the weak and the strong may be equal before the law, but to ensure a more substantive equality the law must be openly solicitous of the vulnerability of the poor, the powerless and the weak. The poor, the powerless and the weak are open to exploitation, and that exploitation is repugnant to their inalienable dignity.

An example is the relationship of employers and employees. In litigation, both may be equal before the law, but that equality will count for nought or little unless the law recognises the reality of the power imbalance which exists between employers and employees. To achieve justice in the individual case, therefore, the law needs to be closely solicitous of this power imbalance to offset the superior power of employers and the possibility or likelihood that the superior power may be used to unfairly disadvantage employees. ${ }^{24}$ So, too, with lenders and borrowers, bankers and customers, insurers and insured, and any other relationship in which the parties do not enjoy a level playing field outside the courtroom. Without this rebalancing in the law the poor, the less powerful and the weak will be open to exploitation and to being unjustly deprived of the equality inherent in the dignity which is theirs as of right. In recognising and making concrete allowance for that imbalance of power the parties are placed on an equal footing in the law.

I eventually saw, when reflecting on this complex subject of justice, that the perception that equality is a factor in achieving justice does not necessarily exclude the converse; at times it may be necessary to treat people unequally in order to do justice. Take a random example: if a litigant is at a physical or other disadvantage in the courtroom, steps will be undoubtedly taken to ensure that the disadvantage is removed or minimised. The litigants will then appear on equal terms or on as equal terms as possible. It is true that the litigant is not being directly exploited by another person, but our sense of justice nevertheless recognises the vulnerability of the disadvantaged litigant and that, without the disadvantage being rectified or minimised, the other person will obtain an unfair advantage.

I came to the conclusion that it is as difficult to determine when equality - or inequality - is part of justice as it is to define justice in the abstract. The answer as to when justice and equality must converge, or when they must diverge, will again be context-specific, but no less real on that account.

This exposition of equality and justice has an important derivative. It invites one to consider more closely the precept of treating like alike and, therefore, the role of precedent or, more particularly, the coercive element in the doctrine of precedent. ${ }^{25} \mathrm{I}$ have long held the view that, if an earlier so-called "binding" decision is unjust, a decision that then slavishly follows it will also be unjust. A decision

24 For a decision which studiously ignores the power imbalance of employers and employees see New Zealand Fire Services Commission v Ivamy [1996] 2 NZLR 587 (CA)

25 See Thomas, above $\mathrm{n} 3$, at ch 6, especially at 251-253. 
does not gain in terms of justice simply because it is consistent with an earlier decision. As Ralph Waldo Emerson so rightly said, "[a] foolish consistency is the hobgoblin of little minds". ${ }^{26}$

\section{VII "THE RIGHT OF THE WEAKER"}

From early days I have cherished a quotation which seemed to me to emphasise what was so often the thrust and direction of the law and what was happening in the courts. Joseph Joubert said: ${ }^{27}$

Justice is the right of the weaker.

Samuel Butler seems to have shared the same sentiment: ${ }^{28}$

For Justice, though she's painted blind,

Is to the weaker side inclin'd ...

I concluded an address in 2000 with this musing: ${ }^{29}$

It may well be that the law has no higher calling than to defend the poor against the mighty, the powerless against the powerful, and the weak against the strong.

Many years later this rhetorical musing became a 14,000 word theory of justice. ${ }^{30}$

\section{THE PRECEPT OF NON-EXPLOITATION}

The theory (which I further expound in the final chapter of The Judicial Process) ${ }^{31}$ is an extension of the concept of corrective justice. In returning the parties to the position they were in before the impeached transaction, it seeks to ameliorate the harsh extremes of individual liberalism and the economic order, capitalism. I perceive the underlying precept of the common law, including equity, to be the law's ultimate abhorrence of exploitation: no person may exploit another in the sense of taking or obtaining an unfair advantage at the other's expense.

26 Ralph Waldo Emersen "Self Reliance" in Emerson's Essays (Sherman Paul (introduction), Everyman's Library, London, 1980) at 57, as cited in EW Thomas "A Critical Examination of the Doctrine of Precedent" in Rick Bigwood (ed) Legal Method in New Zealand: Essays and Commentaries (Butterworths, Wellington, 2001) 141 at 141 .

27 Joseph Joubert was an 18th century philosopher, moralist and writer; the phrase was originally recorded as "[1]a justice est le droit du plus faible" in Recueil des pensées de M Joubert (Le Normant, Paris, 1838) at 325 (English translation: "Collected thoughts of Mr Joubert").

28 Samuel Butler Hudibras (John Wilders (ed), Oxford University Press, Oxford, 1967) at Part 1, Canto 1, line 709.

29 EW Thomas "Centennial Lecture: The Relationship of Parliament and the Courts - A Tentative Thought or Two for the New Millennium" (2000) 31 VUWLR 5 at 36.

30 EW Thomas "The Harkness Henry Lecture: The Conscience of the Law" (2000) 8 Waikato L Rev 1.

31 Thomas, above n 3, at 358 and following. 
In other words, the law serves to protect the weak and vulnerable from the machinations and unfair domination of the strong and powerful. It takes a stand when a person seeks to take advantage of another in a manner or to an extent where it can fairly be said that he or she is abusing the freedom which individual liberalism and the economic order confers on them.

The deep and extended prevalence of this precept of non-exploitation permeates all branches of the law; equity, with its express concern for the vulnerable, of course, but also contract, ${ }^{32}$ tort and public law. Its implementation, I claim, becomes an integral part of the judicial function. In The Judicial Process, I undertake an extensive survey of all branches of the law in order to demonstrate that the precept of non-exploitation is embedded in all branches of the law. But that lengthy survey cannot practicably be repeated here. ${ }^{33}$

\section{AN INTERIM SUMMARY}

Let me bring these strands of thought together. Outside a specific concrete situation justice, or the essence of justice, is difficult, if not impossible, to define. But, nevertheless, in a specific concrete situation justice is very real. Its driving force is empathy; empathy for the poor, the weak and the powerless. From that wellspring, justice will seek to protect the individual by ensuring that the individual is not only equal before the law, but also enjoys substantive equality in the law. That substantive equality is achieved by protecting the poor, the weak, and the powerless from exploitation resulting from any imbalance of power in the interaction or relationship of the persons or entities involved. The imbalance is recognised and rectified in the name of justice.

\section{$X$ GE CUSTODIANS v BARTLE}

I propose to provide a graphic example of the need for courts to forever be sensitive to the dictates of justice. It is the judgment of the Supreme Court of New Zealand in 2010 in GE Custodians v Bartle $^{34}$ and, in particular, one aspect of the reasoning of the Court in reaching its decision. The Court reversed the unanimous decision of the Court of Appeal. ${ }^{35}$ The judgment of the Court ${ }^{36}$ was given by Blanchard J. ${ }^{37}$

32 See also Rick Bigwood Exploitative Contracts (Oxford University Press, Oxford, 2003).

33 Thomas, above n 3, at 375-388.

34 GE Custodians v Bartle, above n 19

35 Bartle v GE Custodians Ltd [2010] NZCA 174, [2010] 3 NZLR 601. The Judges in the Court of Appeal (William Young P and Hammond and Arnold JJ) delivered separate judgments.

36 Elias CJ, Blanchard, Tipping, McGrath and Anderson JJ.

37 For a full critique of this judgment see EW Thomas "A Critique of the Reasoning of the Supreme Court in GE Custodians v Bartle" (2011) 17 NZBLQ 97. As Richard A Posner has argued in How Judges Think (Harvard University Press, Cambridge (Mass), 2008) at 204-219, critiques of a court's reasoning in particular 
While it is to be acknowledged that the Supreme Court is made up of highly intelligent and able Judges, and that the Court has given many splendid judgments, this decision is clearly wrong. The explanation for this judicial lapse is simply that the Court, at least momentarily, lost its moral compass - what could be termed its "justice bearings".

$\mathrm{Mr}$ and Mrs Bartle were an elderly couple. Their only income was New Zealand Superannuation amounting to $\$ 21,336$ per annum. Their sole asset was a modest unencumbered home. In 2006 they were targeted by Blue Chip salesmen ${ }^{38}$ and were persuaded to enter into a joint venture with that company on the promise of a regular monthly income. The Blue Chip salesmen introduced a mortgage broker who arranged a loan from GE Custodians for Mr and Mrs Bartle, secured on their home, to enable them to raise the money necessary to participate in the joint venture. The couple (on an annual income of $\$ 21,376$ per annum) borrowed the sum of $\$ 629,566$. It was this mortgage or loan documents (and not the joint venture being promoted by Blue Chip) that was in issue. ${ }^{39}$

It was accepted that $\mathrm{Mr}$ and Mrs Bartle could not afford the repayments under the mortgage. Indeed, it was common ground that lending of the kind in issue is "asset lending". ${ }^{40}$ Hammond $\mathbf{J}$ in the Court of Appeal, referring to United States jurisprudence, described the mortgage as an "asset sale". ${ }^{41}$ When the inevitable happened and $\mathrm{Mr}$ and Mrs Bartle defaulted on the repayments, GE Custodians took steps to exercise its power of sale.

The question in issue was whether the mortgage was "oppressive" in the terms of s 118 of the Credit Contracts and Consumer Finance Act 2003 and, if so, whether the contract should be reopened under s 120 of that Act. ${ }^{42}$ As the Court subsequently departed from this issue and addressed questions relating to GE Custodian's conduct, knowledge and culpability, it is important to note that Blanchard $\mathrm{J}$ squarely stated the issue in these terms at the outset of the Court's judgment: ${ }^{43}$

[1] Section 120 of the Credit Contracts and Consumer Finance Act 2003 (the CCCF Act) permits, but does not require, a court to reopen a credit contract if, in any proceedings, it considers that the contract is oppressive.

cases can only be of constructive assistance in ensuring that judges achieve the highest possible standard of reasoning.

38 The Blue Chip group was a complex property investment business with various subsidiaries and associate companies. It collapsed in early 2008.

39 Thomas, above n 37, at 99-101.

40 GE Custodians v Bartle, above n 19, at [14].

41 Bartle v GE Custodians Ltd, above n 35, at [78].

42 The Act also extends to "conduct" which may be oppressive: ss 3(g)(i)-(ii) and 120(b)-(c). But the issue was squarely whether the mortgage was oppressive in its terms. GE Custodian's conduct was not in issue.

43 GE Custodians v Bartle, above n 19 (emphasis added and footnotes omitted). 
The Judge then spelt out the definition of "oppressive" in the Act.

Although Mr and Mrs Bartle had their own lawyer, the Blue Chip salesmen persuaded them to take advice from a solicitor, a Mr Mathias, on the basis he understood the scheme, whereas their own solicitor might not. Mr Mathias' practice was heavily dependent on Blue Chip work - as we will see. It is clear that Mr and Mrs Bartle would not have entered into the mortgage but for the advice and assurances they received from Mr Mathias. His advice and assurances were critical to their decision to proceed.

Mr Mathias was held by the Supreme Court to have been "independent", ${ }^{4}$ and it is that finding which is patently wrong. For example, when seeking to refute the view expressed by Arnold $\mathbf{J}$ in the Court of Appeal to the effect that the borrowing could be said to be oppressive because GE Custodians bore little or no risk and Mr and Mrs Bartle faced a high degree of risk (which is wholly correct), the Court commented: "[t]hat was surely a matter for the independent solicitor." ${ }^{45}$ The Court observed that Mr Mathias was Mr and Mrs Bartle's "chosen lawyer" and that it was they who chose to put their faith in him. 46

Mr Mathias's advice was found in litigation in the High Court to be grossly negligent, but that did not avail Mr and Mrs Bartle as Mr Mathias filed in bankruptcy.

Aberrant findings do not suddenly appear "out of the blue", as it were, and, indeed, there is more than a suggestion that the Court had lost its bearings before it approached the question whether $\mathrm{Mr}$ Mathias was "independent". There is no lack of "red flags".

Referring to 10 "red flags" will suffice.

In the first place, the mortgage was a subprime mortgage. It had been specifically structured as a subprime mortgage. ${ }^{47}$ The mortgagee was a subsidiary of a conglomerate in the United States which was among the top ten subprime mortgage companies in $2006^{48}$ with a loan value of $\$ 33.2$ billion amounting to 5.5 per cent of the subprime mortgage market in that country. It possessed all the characteristics of, and met all the criteria for, a subprime mortgage. It was a subprime mortgage with

44 At [53] and [66].

45 At [64].

46 At [68].

$47 \mathrm{Mr}$ and Mrs Bartle could not qualify for a conventional or prime mortgage because of their modest income; they were not required to verify their income; the mortgage provided for a higher interest rate than that applying to conventional or prime mortgages; and interest only was charged in the short term before the instalments of principal and interest became payable for the balance of the term. They borrowed $\$ 629,500$ and placed at risk their only asset, their home, valued at the time at $\$ 393,000$. The amount required to meet interest payments alone was $\$ 61,000$. (Recollect that Mr and Mrs Bartle's annual income was $\$ 21,736$.)

48 The year in which the loan documents were executed. 
bells on. Yet, nowhere in the judgment, 68 paragraphs in length, is there any mention of the fact that the mortgage in issue was a subprime mortgage. To fail to acknowledge that the mortgage was a subprime mortgage and, therefore, the predatory nature of the mortgage, was to ignore the elephant in the room.

To the contrary, and in the second place, the Court seems to have thought that the mortgage was consistent with commercial practice. It frequently refers to the closing phrase in the s 118 statutory definition of the word "oppressive": "... or in breach of reasonable standards of commercial practice". Suffice to say that the many mortgage companies in this country that had declined to offer subprime mortgages would be somewhat surprised to learn that predatory lending complied with "reasonable standards of commercial practice".

The odd failure to call the mortgage a subprime mortgage is not just a matter of calling a spade a spade. Had the Court felt obliged to disclose that the mortgage was a subprime mortgage it might, and should, also have felt obliged to refer to the case law in the United States. ${ }^{49}$ The courts in that jurisdiction have taken an entirely different approach. Subprime mortgages are unhesitatingly described as predatory lending ${ }^{50}$ which, of course, they are. ${ }^{51}$ Another overseas decision which also takes the opposite approach to the Supreme Court in this case is the decision of the New South Wales Court of Appeal in Fast Fix Loans Pty Ltd v Samardzic. ${ }^{52}$

Thirdly, the Credit Contracts and Consumer Finance Act is one of a number of Acts explicitly enacted for the protection of consumers. Not once is this express legislative purpose and intent, amounting to nothing less than a statutory directive to the courts, acknowledged.

Fourthly, the Court chose to reinterpret the statutory definition of "oppressive". "Oppressive" is defined as "oppressive, harsh, unjustly burdensome, unconscionable, or in breach of reasonable standards of commercial practice". ${ }^{53}$ The definition provided the Court with a range of disjunctive meanings, any one of which might have been thought appropriate on the facts of this case. Instead, the Court adopted the dicta of Tipping J in Greenbank New Zealand Ltd $v$ Haas $^{54}$ and imposed a gloss on the statutory definition which, because the oppression had to be in breach of reasonable standards

49 See for example Commonwealth v Fremont Investment \& Loan 897 NE 2d 548 (Mass 2008).

50 See for example Commonwealth v Fremont Investment \& Loan, above n 49; Commonwealth v H\&R Block Inc 25 Mass L Rep 92 (Mass Super 2008); and Wells Fargo Bank, NA v White (Me Super, 5 September 2014).

51 Subprime mortgages can be offered to borrowers who are asset rich but cash poor. But the facts of this case are far removed from those circumstances. Mr and Mrs Bartle were asset poor and cash poor.

52 Fast Fix Loans Pty Ltd v Samardzic [2011] NSWCA 260, (2011) 15 BPR 29,445. The loan is this case was not a subprime mortgage. It was, however, described as a case of "asset lending".

53 Credit Contracts and Consumer Finance Act 2003, s 118.

54 Greenbank New Zealand Ltd v Haas [2000] 3 NZLR 341 (CA) at [24]. 
of commercial practice, had the effect of making mortgagees generally the arbiters of what is or is not an oppressive mortgage..$^{55}$

The fifth point arises out of this decision. The proceeding in Greenbank was an appeal from the decision of a Master striking out a claim that the transaction in issue was oppressive (and the result of undue influence). The definition of oppressive adopted by Tipping $J$ in that case came with a firm caveat; it was not for judges to decide what was or was not in accord with reasonable standards of commercial conduct. Indeed, Tipping J had some stern words for judges who take an "intuitive" or "impressionistic" approach to this question. ${ }^{56}$ To determine what accords with reasonable standards of commercial conduct the courts must be "properly informed" and, other than in the plainest of cases, "evidence will need to be led". 57

There was, it is to be emphasised, no such evidence in the Bartle case. Thus, the Court adopted Tipping J's extra-statutory interpretation of the word "oppressive" but then ignored the firm caveat that the courts need to be properly informed by evidence in all but the plainest of cases as to what constitutes reasonable standards of commercial conduct.

Sixthly, the Court avoided Mr and Mrs Bartle's counsel's argument that the mortgage was oppressive in its terms ${ }^{58}$ In doing so it also departed from its own definition of the question in issue at the outset of its judgment, ${ }^{59}$ and introduced a requirement that the mortgagee must know of the factors making the mortgage oppressive, or of factors which should have put the mortgagee upon inquiry, before the mortgage is oppressive for the purposes of the statute. This is to say, a mortgage which is oppressive in its terms is not oppressive for the purposes of the statute unless the lender knows that it is oppressive or knows of the factors which should put it upon inquiry as to whether it is oppressive. But as Arnold J had pertinently said in the Court of Appeal: "[i]f the legal adviser does not fulfil the role [of providing independent advice] adequately, the oppression remains". ${ }^{6}$

That must be so. If a transaction is horribly oppressive but, for whatever misguided reason, the borrower's lawyer tells his or her client it is not oppressive, the transaction is still horribly oppressive.

55 There is no compelling reason why the closing phrase in the definition "or in breach of reasonable standards of commercial practice" should not be also treated disjunctively (emphasis added). A credit contract which, say, has been adopted by the finance industry as standard practice may nevertheless be "oppressive" on the basis of any one or more of the meanings contained in the definition. For a more general condemnation of the tendency for appellate courts to adopt alternative wording to interpret a statutory provision when alternative wording is unnecessary see Thomas, above n 3, at 267.

56 Greenbank, above n 54, at [25].

57 At [24]-[25].

58 See above $\mathrm{n} 43$ and the corresponding quotation in the text.

59 Above $\mathrm{n} 43$.

60 Bartle v GE Custodians Ltd, above n 35, at [227]. 
It must be that elephant the Supreme Court harboured in this case. If you see an elephant and the zookeeper, for whatever bizarre reason, tells you that it is not an elephant, it is still an elephant.

Seventhly, the Court's opinion is overly mortgagee friendly. To many, it will suggest an inbuilt bias. Why should the mortgagee be entitled to make an assumption that the borrower has had proper independent advice in legislation explicitly aimed at protecting the consumer? There is no scope under the legislation for assumptions of any kind. If the borrower has had advice that is not independent the advice is, as a matter of fact, not independent, irrespective of any assumption the mortgagee might make. The legislation is purposely designed to protect the borrower, not the lender.

In addition to also highlighting the lack of logic in the Court's reasoning, this inbuilt bias in favour of mortgagees becomes transparent if the appropriate interpolations are injected into the Court's finding: a mortgage which is oppressive in its terms (to the detriment of the borrower) is not oppressive if the mortgagee does not know of the factors that make the mortgage oppressive (to the benefit of the mortgagee, who is then free to enforce a mortgage which is oppressive to the borrower).

Eighthly, the Court declared that the case raised, apparently for the first time, the question of whether a credit contract can be found to be oppressive if the lender has no knowledge of matters external to it which might otherwise lead the Court to the view that there was "oppression". ${ }^{61}$ Rather than referring to the Credit Contracts and Consumer Finance Act itself as the logical starting point to determine the answer to that question, the Court launched on what can only be described as series of musings. Blanchard J, speaking for the Court, said the Court was not aware of any case where it had been contended under the Act or its predecessor, the Credit Contracts Act 1981, that the lender was unaware of circumstances material to the existence of oppression. ${ }^{62}$ It is unlikely, Blanchard J mused, that in cases where it is said the terms of the credit contract are oppressive, or that the lender itself has acted oppressively, the lender would be able to deny knowledge of the factor or factors which are complained of. ${ }^{63}$ In the present case, the learned Judge asserted, the oppression is said to arise from a combination of the personal situation of the Bartles and the arrangements they entered into with Blue Chip over the purchase of the apartment. ${ }^{64}$

The Court opens itself to a slew of criticism with such ill-thought-out reasoning:

- It is an odd use of prior case law to rely on the claim that the Court was not aware of any case where it had been contended that the lender need not have knowledge of the factor or factors which make the contract oppressive because neither is there any prior case where it has been held that the lender must or should have such knowledge. The claim is not only an

$61 G E$ Custodians v Bartle, above n 19, at [45].

62 At [45].

63 At [45].

64 At [45]. 
odd use of prior case law, but also a defiant denial of respectable judicial reasoning. Imagine the Court holding that to be guilty of murder the accused must have a third eye in the middle of his or her forehead and, as the reason for that startling finding, stating it is not aware of any prior case in which it has been held that to be guilty of murder the accused need not have a third eye in the middle of his or her forehead! Or, again, imagine the Court ruling that to be enforceable a contract must be printed on green paper, and asserting as authority for that ersatz opinion that the Court is not aware of any prior case in which it has been held that to be enforceable a contract does not have to be printed on green paper. The Court must struggle to avoid the charge that this key statement in its reasoning is nothing short of banal. ${ }^{65}$

- The emphasis on the phrase, "or that the lender itself has acted oppressively" indicates that the Court lost sight of the clear distinction between a contract alleged to be oppressive in its terms and conduct alleged to be oppressive. ${ }^{66}$

- The Court recites that the "oppression" in the present case "is said to arise from a combination of the personal situation of the Bartles and the arrangements they entered into with Blue Chip over the purchase of the apartment". ${ }^{67}$ This assertion not only grossly misstates Mr and Mrs Bartle's case, that is, that the mortgage was oppressive in its terms, but also clearly departs from the issue as defined by the Court in the opening paragraph of its judgment. ${ }^{68}$ The arrangements $\mathrm{Mr}$ and Mrs Bartle entered into over the purchase of the apartment and the conduct of GE Custodians - and Blue Chip - are irrelevant to the question whether the mortgage was oppressive in its terms. ${ }^{69}$

- Most importantly, and as already touched upon, if it is thought the case raised a new question, that is, whether the lender had to have knowledge of the oppressive factor or factors for the mortgage to be oppressive, the logical place for the Court to start and, indeed, finish, is with the Credit Contracts and Consumer Finance Act itself. There would have been only one tenable answer if this exercise had been undertaken. Both the wording, including the distinction the Act draws between a credit contract which is oppressive in its terms and conduct which is oppressive, ${ }^{70}$ and the purpose and intent of the legislation, clearly confirm that the lender's knowledge is irrelevant to the question whether a mortgage is oppressive.

65 One may, if one so chooses, imagine any number of variants of this reasoning while, say, patiently waiting for the traffic lights to change.

66 GE Custodians v Bartle, above n 19, at [45].

67 At [45].

68 See above $\mathrm{n} 43$ and the corresponding quotation in the text.

69 Blue Chip, of course, was not a party to the proceeding.

70 Credit Contracts and Consumer Finance Act, s 3(2)(d). 
It is this feature of the judgment, that the lender has to have knowledge of the factors which make the transaction oppressive for the transaction to be oppressive, that has attracted the most attention and, indeed, curiosity. Attention, because it is the core ratio of the judgment, and curiosity because it is not clear where the requirement came from. As indicated, it cannot be found in the prior case law. It cannot be inferred from the wording in the definition in the statute. Indeed, it is negated by the wording. And it is clearly contrary to the intent and purpose of legislation expressly designed to protect consumers. $^{71}$

Ninthly, and returning to the "red flags", the Court asserted that it would be wrong to hold GE Custodians "culpable" when Mr and Mrs Bartle were receiving advice from a solicitor whose independence must be accepted. ${ }^{72}$ The use of language such as "culpable" is puzzling. The issue is whether the transaction is oppressive and the "culpability" of the mortgagee is irrelevant. Such a question would or might be relevant if the "conduct" of the mortgagee was in issue, but as has been repeatedly emphasised, this is not such a case.

Finally, and in the tenth place, Blanchard J, speaking for the Court, firmly declared that to hold the mortgage oppressive when the mortgagee did not know of the factor or factors which made the mortgage oppressive would "make bad law". ${ }^{73}$ The point here is not that the Court did in fact make very bad law, but that the Court did not do what the statute clearly commands. A requirement that the lender know the factor or factors which make the mortgage oppressive is not a minor gloss on the Credit Contracts and Consumer Finance Act. It has a major impact on the meaning and scope of the statute. Indeed, the impact is so far-reaching that Parliament would undoubtedly have expressly included the requirement if it had intended it to be part of the statutory regime. The policy decision had been made with the enactment of the statute.

So, perhaps, the astute reader is already steeled for the onset of a blatant error in respect of its finding that Mr Mathias was "independent". ${ }^{74}$

These are the relevant facts:

71 In the result, the Court focussed on the question whether the knowledge of the mortgage broker, which had the relevant knowledge, could be attributed to GE Custodians, which did not have direct knowledge.

72 GE Custodians v Bartle, above n 19, at [67].

73 At [68].

74 It cannot be tenably claimed, if the claim were to be made, that Mr Mathias's "independence" had not been put in issue. See my response to any attempt to shift responsibility to counsel in Thomas, above n 37, at 119. In the circumstances and having regard to the trial Judge's findings of fact, it was incumbent on the Court, both to protect its adjudicative integrity and in fairness to the parties, to look at the substance of the issue. 
(1) Mr Mathias was not their own lawyer; Mr Mathias was strongly recommended by the Blue Chip salesmen. ${ }^{75}$

(2) At times during their pursuit of a "sale" to Mr and Mrs Bartle, the Blue Chip salesmen conferred with Mr Mathias in respect of that "sale".

(3) Blue Chip work formed a substantial proportion of Mr Mathias's sole practice.

And this is the substantial proportion of Mr Mathias's sole practice:

(1) He had about 150 clients who were Blue Chip investors making up approximately 75 per cent of his practice.

(2) He represented 50 to 60 Blue Chip investors in 2006.

(3) He employed two staff members to specifically handle Blue Chip's conveyancing work.

(4) In addition to the fee he recovered from Mr and Mrs Bartle on the mortgage, Mr Mathias received the fees for carrying out the mechanical work associated with the registration of the mortgage from Blue Chip.

Needless to say, Mr Mathias had never previously advised any one of the many "clients" who were sent to him for advice by the Blue Chip salesmen to reject the predatory mortgage in issue.

Another telling point may be added to this formidable list; Mr Mathias's failure to advise Mr and Mrs Bartle of the number of real and potentially fatal risks to them in entering into the mortgage in itself indicated he was seriously compromised. It is surely beyond question that an independent solicitor would have advised Mr and Mrs Bartle that they simply did not have the capacity or resources to repay the mortgage payments as they fell due, that as a result of not having the capacity or resources to repay the mortgage payments as they fell due they would default in making the payments due under the mortgage, and that on that default their home would be forfeited to GE Custodians. He literally failed to advise $\mathrm{Mr}$ and Mrs Bartle of the inevitable.

No one with a modicum of objectivity would accept that Mr Mathias was remotely worthy of the description of "independent". He may as well have been Blue Chip's in-house lawyer. He was incapable of discharging the solicitors' fundamental fiduciary duty to $\mathrm{Mr}$ and Mrs Bartle.

It will be readily apparent that the decision in this case is contrary to every sentiment expressed in these reflections on justice. Certainly, other than acknowledging that the decision would be "hard" on $\mathrm{Mr}$ and Mrs Bartle, ${ }^{76}$ there is no overt, if any, attention to the justice of the case. The decision can hardly claim to be even-handed when it explicitly favours the mortgagee, or the interests of mortgagees generally over the interests of borrowers; it displays little or no empathy or empathetic concern for the vulnerability of $\mathrm{Mr}$ and Mrs Bartle; it does not address the inequality in the relative positions and power of GE Custodians and Mr and Mrs Bartle when, indeed, the Credit Contracts and

75 As to be expected, the remuneration of the salesmen was related to the "sales" they made.

76 GE Custodians v Bartle, above n 19, at [67]. 
Consumer Finance Act is founded on Parliament's perception of the imbalance of power between creditors and lenders (among others) on the one hand, and those who are vulnerable to the possibility of commercial abuse, on the other; ${ }^{77}$ and its untoward focus on the interests of the mortgagee seem to preclude even a passing regard for society's expectation that the courts will deliver justice in the individual case. Finally, it is a standing refutation of the theory of justice advanced above based on the precept of non-exploitation; the strong and powerful (here a subsidiary of a vast conglomerate in the United States "selling" predatory subprime mortgages as part of a scheme being promoted by financially motivated salesmen (who then referred the borrowers to the solicitor they themselves worked with) was effectively pardoned for its exploitation of the weak and vulnerable (Mr and Mrs Bartle, a retired, unsophisticated couple on superannuation with no commercial experience). ${ }^{78}$

As already suggested, the Court's failure to address the power imbalance between GE Custodians and $\mathrm{Mr}$ and Mrs Bartle is painfully acute in this case as the Credit Contracts and Consumer Finance Act effectively makes it mandatory for the respective positions of the lender and borrower to be addressed. The borrower is to be protected from being exploited by the lender.

When confronted with an allegedly bad decision some judges will seek to shift the responsibility to counsel. Counsel's argument, it will be said, was inadequate or deficient. It cannot be accepted that this pitiable excuse is applicable in this case. Certainly, the question whether the mortgagee had to know that the mortgage was oppressive for the mortgage to fall foul of the statute was outside counsel's argument that the mortgage was oppressive in its terms (as well as the Court's own definition of the issue in the case). ${ }^{79}$ But the facts were clear. They come from the Court's own judgment and the judgments of the Courts below. They were known to all members of the Court.

And the notion that a "tame" solicitor cannot be considered independent had been rehearsed in oral argument. Tipping J said: "[y]ou can't be both tame and independent, surely?" But, notwithstanding the validity of this observation, an argument to that effect did not endure.

So, although the language may seem extreme, it is not going too far to suggest that at this point the Supreme Court malfunctioned; it failed to find the essential facts, it strayed from the issue that it had itself defined, and its analysis and application of the law was badly flawed. ${ }^{80}$ How did this come

77 Thomas, above n 37, at 103-104.

78 If the facts of this case had existed before the enactment of the Credit Contracts and Consumer Finance Act, the Minister introducing the Bill, and every member who spoke in favour of the Bill thereafter, would undoubtedly have referred to these facts as stark evidence of the need for the legislation.

79 See above $\mathrm{n} 43$ and the corresponding quotation in the text.

80 The decision was a decision of the Supreme Court and that Court must accept responsibility for it, but one does not have to delve more than four or five pages into the transcript of oral argument to perceive that the "running" is being made by members who previously sat on the Court of Appeal before the Supreme Court was established, that is, the Court of Appeal known as "the Richardson Court". 
about? How did five intelligent Judges with formidable judicial talents reach a finding that is clearly aberrant?

The explanation is that the Court lost its moral compass - its "justice bearings". It would have required only one Judge to say in conference: "[i]n asserting that Mr Mathias is independent, are we being fair to Mr and Mrs Bartle?" ${ }^{81}$ and the facts and statute would have been re-examined and, with that added scrutiny, the finding would almost certainly have been abandoned as factually and logically unsustainable.

It is important to note that it is not being said that the Court would have found Mr Mathias was not independent simply because any other outcome would be tragic for Mr and Mrs Bartle. Rather, the claim is that, if the Court had not lost its moral compass - its justice bearings - it would have been motivated to have had closer regard to the facts and to the wording and the purpose and intent of the Credit Contracts and Consumer Finance Act in order to ensure that justice was done. In the course of doing so it would have assuredly reached the correct decision in fact and law.

And so, the opportunity to exercise the wide remedial powers conferred on the courts under the statute was lost. Had the Court declared the mortgage "oppressive" it would have been possible, for example, to vest the freehold in GE Custodians and give Mr and Mrs Bartle a life interest in the property or, simply, as I would have preferred, deprive the GE Custodians of the fruits of its predatory lending.

As already said, the hallmark of legal reasoning is analytical and logical thinking. Such analytical and logical thinking was painfully absent in this case. The true facts relating to the "independence" of Mr Mathias were ignored or distorted to the point that the Court was effectively saying "black is white". And there is no gainsaying the fact that the judgment is marked by a mind-numbing lack of logic. Divorced from the underlying value of justice, the Court's reasoning became an exercise in assembling words empty of meaning - just a game.

And so the Court reversed the decision of the Court of Appeal, and Mr and Mrs Bartle at once became homeless and destitute.

The costs order against GE Custodians in the Court of Appeal was reversed and Mr and Mrs Bartle were ordered to pay that company costs of $\$ 25,000$, together with reasonable disbursements. The amount of this award, it will be noted, exceeded Mr and Mrs Bartle's annual income of \$21,336. It is difficult to explain why the Court made a punitive award of costs against $\mathrm{Mr}$ and Mrs Bartle. It cannot

81 The same or similar question could have been asked in respect of the other "red flags" briefly discussed in the text. 
be suggested that their case was frivolous as Mr and Mrs Bartle had succeeded in the Court of Appeal. ${ }^{82}$

Moreover, and it almost goes without saying, the Court created a hole in the Credit Contracts and Consumer Finance Act that a Swiss cheesemaker would be proud to own.

\section{CONCLUSION}

The search for justice in the abstract, or for the essence of justice, proved disappointing. It is difficult, if not impossible, to discern its abstract meaning or its essence. Justice is nevertheless real. But it is incorrigibly context-specific. It is, however, for that very reason pertinent to the administration of the law simply because the law administered in the courts is necessarily concerned with the context-specific situations of individuals. Empathy or an empathetic concern for the poor, the weak and the powerless prompts a consideration of justice on the facts of any given situation. It is just decisions in these individual cases that then give the law its moral direction.

Nevertheless, one important perception of justice emerges, that is, that the law seeks to protect those that are vulnerable from being exploited or unfairly taken advantage of by those who are in a position of dominance or power. This precept of non-exploitation becomes embedded in the law and ensures that justice is done between persons notwithstanding any imbalance of power between them. So it is that justice is done in accordance with the law.

The case study, GE Custodians v Bartle, provides a disturbing example of what happens if a court does not have regard to the justice of a case. Assertions take the place of reasoning. Thus, the Supreme Court asserted that the predatory subprime mortgage in issue complied with reasonable standards of commercial practice; it asserted that the predatory mortgage was not "oppressive" for the purpose of the Credit Contracts and Consumer Finance Act; it asserted that the lender must know of the factor or factors which make the mortgage oppressive or know of the factor or factors which should put it upon inquiry, and pressed for a reason to justify such a claim; it asserted that the Court was not aware of any prior case which holds that the lender does not have to know the mortgage is oppressive; and it asserted that the hopelessly compromised solicitor who gave Mr and Mrs Bartle critical advice was "independent". 83 The absence of any concern for justice resulted in a decision that is an outright

82 There is something mean-spirited about a decision which not only neglects the fact that Mr and Mrs Bartle were the victims of predatory lending, but also then rebukes them with a punitive award of costs for challenging the statutory legality of that predatory lending.

83 Standard judicial reasoning would, for example, have required the Court, having set out the facts relating to Mr Mathias's practice as set out in the text, to then say something along these lines: "nevertheless, we find that Mr Mathias was independent for the following reason or reasons ...". No such exercise was attempted, and so the finding that Mr Mathias was independent remains a bald assertion clearly contrary to the established facts. 
refutation of the true facts of the case, is stoically indifferent to the protection provided to borrowers under the Credit Contracts and Consumer Finance Act and is undeniably mind-numbingly illogical.

And so it was that Mr and Mrs Bartle became the victims of a most grievous injustice.

\section{A PERSONAL NOTE IN CLOSING}

Tomorrow, after 16 years, my sinecure as a Distinguished Visitor at the Auckland Law School comes to an end. The time I have been here has been one of the happiest times of my professional life. My respect and admiration for the Faculty members and, indeed, all academics, is unbounded. I have found them to be dedicated and conscientious to a fault. They are true professionals. I will miss them.

Tonight, they have given me a gift beyond value. From the beginning of my studies at the Victoria University of Wellington Law School, I have loved the law. My presence at this Law School has permitted me to prolong and indulge my love of the law for 16 years past my statutory use-by date. And for that I will be forever grateful.

And tonight the Dean, and the Law Faculty, have given me the opportunity to finish off reflecting on justice. And for that I will also be forever grateful.

For, as tonight's lecture confirms, I am under no illusion:

Although I have loved the law, I have loved justice more. 
